\title{
The Effect of Competitiveness Toward Economic Performance in Regencies/Cities At East Java
}

\author{
Muhammad Sri Wahyudi Suliswanto ${ }^{1}$, Sutikno² \\ ${ }^{1}$ Universitas Muhammadiyah Malang, Indonesia \\ ${ }^{2}$ Universitas Trunojoyo Madura, Indonesia \\ mswahyudi@umm.ac.id
}

\begin{abstract}
This research is intended to analyze the competitiveness of regions to economic performance in each district/city in East Java Province. This research uses regression tool of panel data with approach of random effect model. The results of this study indicate that the indicators that have a big role on economic performance are the aspect of public services. So the priority of policy in general is the improvement of public service in terms of order of regulation/regulation, provision of infrastructure, and readiness of human resources. Improving the quality of human resources should also be a priority because based on the results of research indicates that variable human resources is an important factor in the formation of competitiveness.

Keywords: competitiveness, economic performance, East Java.
\end{abstract}

JEL $\quad$ : M48

DOI : : 10.24002/kinerja.v22i2.2122

Received : 11/16/2019 Reviewed: 2/6/2019_ Final Version: 2/14/2019

\section{INTRODUCTION}

The regional development which aimed to achieve community welfare should be done by sustainable development. Sustainable development is one of the developments that are able to fulfill the human needs nowadays without overlooking about human capability towards human needs in the future (Brundtland, 1985). The sustainable development has become the main focus on the development and construction in regencies/cities in Indonesia. In the development of regencies/cities in Indonesia, there are five basic principles to do development in regencies/cities, 
namely environment (ecology), economy (employment), equity, engagement, and energy (Budihardjo \& Sudjarto, 1999). There are four parameters with micro-scope in order to achieve the sustainable action of development of regencies/cities in Indonesia, which are livability, competitiveness, bank ability, good governance and management (World Bank Institute, 2001).

Autonomy and economy globalization era has a significant to achieve virtuous developing in region, which is competitiveness (Kaluge and Suliswanto, 2010; Suliswanto, 2016). Using the level of competitiveness as the parameter in sustainable action of development becomes deliberate for the regencies/cities. Irawati, et al. (2008) has differentiated the level of relative competitiveness among regencies/cities in South Sulawesi. This research take the aim on the lookout for how the superiority from regencies/cities would take responsibility to ease problems in development area; in which based on three variables as the basic ground, namely economy level of territory, availability of tool and infrastructure, also availability of human resources. The three basic variables were comparison that had been publishing from several experts, such as: (Abdullah, Alisjahbana, \& Efendi, 2002), (Porter, 1990), World Economic Forum (WEF), Institute of Management Development (IMD), Department of Trade and Industry of UK (UK-DTI), Centre for Urban and Regional Studies (CURDS), The Bulgarian Competitiveness Initiative, Kenyon (Western Australia Planning Commision), Fanstein, Thomas (www.beaconhill.org), Education Center and Central Banking Studies of Bank Indonesia, and Faculty of Economy of UNPAD, World Bank Institute.

Furthermore, Irawati, et al. (2008) found that Buton, Bau Bau, Kendari, and Kolaka are regencies that have special function was supported by the good result of competitiveness for excellent variables in each regencies / cities. The best ranking of competitiveness based on regional economic, infrastructure and human resource in regencies/cities in South Sulawesi is one of the supporting factors to reach the best ranking in general.

Santoso (2009) does another research related to regional competitiveness. This study measures the level of competitiveness of a city with the main factors (input) and economic performance (output). The main factors of competitiveness comprise 5 main indicators, namely (1) productive business environment, (2) regional economy, (3) manpower and human resources, (4) infrastructure, natural resources and environment, (5) banking and financial institutions, whereas the economic performance (output) includes labor productivity, employment rate, and Gross Regional Domestic Product (GRDP) per capita.

The study was conducted mapping of 24 major cities in Indonesia outside Jakarta, which has a population of approximately 500,000 people upwards. Competitiveness of the city is done by rank them based on these significant factors. Competitiveness of the city mapping is done by grouping the big cities based on the performance of input and output indicators. The results of the grouping obtained the level of city efficiency in achieving high city competitiveness. Major cities that have 
high competitiveness and efficiency levels related to the performance of input indicators and output indicators are Batam and Balikpapan City.

The Regional Autonomy Implementation Monitoring Committee (KPPOD) with the United States Agency of Improvement and Development (USAID) and The Asia Foundation (KPPOD, 2007) has also conducted studies on the competitiveness of regencies / cities in Indonesia. This study focused on the competitiveness seen from the aspect of regional investment in 169 districts and 59 cities across Indonesia. Indicators to measure regional competitiveness and competitiveness ratings of each region based on five categories of support, for example institutions, regional economics, socio-cultural security politics, physical infrastructure, and labor.

The result of this study related to the current districts/cities in the region of East Java Province showed that: First, from 59 cities surveyed there are two cities in East Java have a notation $A$, namely Surabaya ranked $13^{\text {th }}$ and Kediri ranked $16^{\text {th }}$. Two cities fall into B notation category, they are Malang ranked $34^{\text {th }}$, and Mojokerto ranked $37^{\text {th }}$, meanwhile $C$ notation drops to Probolinggo ranked $48^{\text {th }}$. The last is Madiun, ranked $56^{\text {th }}$, in $\mathrm{D}$ notation.

Secondly, from the total of 169 surveyed district areas, there were a district with predicated $A$ in ranked $8^{\text {th }}$ which surveyed in East Java which was Sidoarjo district. Furthermore, district in ranked $39^{\text {th }}$ with predicated B was Gresik district. Kediri, ranked $65^{\text {th }}$, is predicated C. There were six districts predicated D respectively, Banyuwangi district ranked 95th, Mojokerto district ranked $97^{\text {th }}$, Jombang district ranked $100^{\text {th }}$, Bangkalan district in ranked $107^{\text {th }}$, Magetan district $118^{\text {th }}$, and Blitar district $125^{\text {th }}$. While, there were eight districts predicated $\mathrm{E}$ respectively, Tulungagung district ranked $139^{\text {th }}$, Situbondo ranked $141^{\text {th }}$, Jember district ranked $153^{\text {th }}$, Pasuruan district $158^{\text {th }}$, Ponorogo district $159^{\text {th }}$, Lamongan district ranked $161^{\text {th }}$, Bondowoso district ranked $165^{\text {th }}$, and Pamekasan district ranked $166^{\text {th }}$.

Based on the two studies about regional competitiveness of province, it is shown that East Java's competitiveness has a good rank which is rank two from 33 province surveyed. At the province level, only Jakarta that beat East Java level of competitiveness. However, from the result of competitiveness research in district/city, it shows that the result is deficient. It's the same with the research's result conducted by KPOD which explained above; it showed that most of area in East Java $47.6 \%$ predicates $\mathrm{E}$ and $35.25 \%$ predicate $\mathrm{D}$. While, areas that are predicated $A$ and $B$ are only $5.8 \%$ respectively.

Imbalance or inequality development in East java reinforce with the macroeconomic indicators such as Gini Ratio index and the employment. Gini's coefficient is the fairness size which measured by comparing larger area between diagonal and Lorenz curve (A area) divided by the area of triangle below the diagonal which show the number range of zero (perfect equalization) one (perfect imbalance). Below the conditions of development equalization in East java based on Gini Ration index value for the last five years. 
Referring to Gini ratio value, the average of per capita consumtion imbalance level in East Java 2009-2012 is still in medium category (between 0.3-0.5). During 2011-2015 gini ratio value in east java shows the enchancement from 0.36 in 2011 become 0.42 in 2015 (Badan Pusat Statistik Jawa Timur, 2017). In that situation, it is still better than comparing with gini ratio national value in 2011 was 0.40 become 0.42 in 2015 (Badan Pusat Statistik, 2017). For this reason, the magnitude of increasing the average value per capita since 2011-2015 and increasing presentace non comsumtion food suspected to be imbalance to all people. This condition as cause of imbalance in the consumtion distribution.

Based on the data, it is shown that there are some development problems included imbalance or inequality development in East Java. Thus, the regional autonomy should be able to rearrange and design an appropriate plan of the district or city in East Java which nowadays not yet effective. The socio-economic community gathered with the government in east java needs to structuring and planning especially in attempt to maintain the economic growth, expanding of employment opportunities, and increasing value adding the development of others productive activities. The aim of that condition is to support the optimization and the regional competitiveness to gaining the better equally in quality development in East Java.

Based on the empirical result, the higher level of district or municipaltiy regional competitiveness, the higher growth rates and wellbeing in society will achieved. However, the variables measured in measurement regional competitiveness level still diverse depend on each area condition. Therefore, this is what theoritically still gives due to the theory gap; it needs continously research to develop the measurement indicators regional competitiveness in East Java with use the power of area, public service facilities, and the investment climate. The indicators are different with the previous study.

Beside the theory contidition, the empirical condition of East Java's competitiveness is also the background of this research, as will be discussed below. Based on the condition problem in East Java province which explained above, the aims of this study are: 1) to analyze the typology regional competitiveness in district or municipality region which included in the administrative area of east java; 2) to analyze the influence of regional competitiveness from the district or municipality region on economic performance in each district or municipality which included in the administrative east java province.

\section{RESEARCH METHODOLOGY}

The scope of this study include the steps below: firstly, analyze the typology of economic performance with the regional competitiveness, it was done with comparing between economic performance and regional competitive, thus it could be devided into four quadrants which are: I category (high economic performance 
and competiveness); category II (high economic performance but low competiveness); category III (low economic performance but high rivalry); dan kategori IV (both economy and competitiveness low).

The regional competitiveness value inter district or city based on the value of regional power aspect, public facility and investment clime done by sum of value from standardized with the priority weight of each indicator in each variable. The three aspect of regional competitive will be analyzed below: aspect the regional power which includes PDRB per capita, literacy rate, and the participation value of SD/MI/Paket $A$, the value of enrollment rate of SMP/MTS/Paket $B$, the value of enrollment rate of SMA/SMK/MA/Paket $C$, Percentage of population aged 15 years and above by certificate SD/MI, Percentage of population aged 15 years and above by certificate SMP/MTS, Percentage of population aged 15 years and above by certificate SMA/MA, Percentage of population aged 15 years and above by certificate university, and IPM.

There are many aspects of public service which are the ratio availability of school or school-age dwellers, teachers or students. There are also classrooms of primary school, junior high school, and senior high school that are in good condition. Besides those mentioned, the aspect also includes the health service, environmental hygiene, the availability of sports area, active coop, social security service and availability, and tourism visitors.

In addition, there is also an infestation of climate aspect which consists of purchasing power index, farming area, infestation business unit, the amount of infestation, and Industry Development. Numbers of economic development is used in the Economic Performance. Regression data panel with random effect model approach is used in the analysis of the competiveness influencing on economic performance. This model is chosen because every region has its own score. It proves that every region has different characteristics.

\section{RESULT AND DISCUSSION}

\subsection{The Typology of Competiveness in each region or city in East Java}

This typology of competiveness analysis is the modification of Klassen typology research by Syafrizal (1997). Hence, to know regional competiveness clarification, it is based on the two main indicators, Regional Competiveness and Economic Performance. This typology is used to know the pattern of Competiveness compared to the Economic performance in each of East Java's district or city. Moreover, based on the analysis, the region in $1^{\text {st }}$ category (both Economic Performance and Competiveness is high) is the district of Malang, Banyuwangi, Sidoarjo, Mojekerto, Jombang, Gresik. Several cities like Kediri, Malang, Mojokerto, Mediun, Surabaya, and Batu are also included. The regions that included in the $2^{\text {nd }}$ category (high Economic performance but low Competiveness) 
are the district of Bojonegoro, Nganjuk, Lamongan, Pasuruan, Jember, Lumajang, Kediri, Blitar, Tulungagung, and Trenggalek.

The regions that included in the 3rd category (low Economic Performance but high Competiveness) are districts of Ponorogo, Magetan, Ngawi and also Blitar and Pasuruan city. Furthermore, there are Sumenep, Pamekasan, Sampang, Bangkalan, Tuban, Madiun, Probolinggo, Bondowoso, Situbondo and Pacitan District in the $4^{\text {th }}$ category (both Economic Performance and Competiveness are low).

It will be explained in more detail about the analysis of region strength typology that shows the position of a district or city. And it will also explain about the factors that influence a district or city located in the quadrant position. First is Quadrant I. Quadrant $I$ is quadrant that indicates both high economic performance and competiveness. A district or city that is included in quadrant I tend to be industrial area or has comparative and competitive privilege. Malang district and Batu city are included in Quadrant I due to the farming resource that is large compared to others. Besides, typologically, both of their public services and climate infestations are in the top ranking of 38 districts. It means that Malang district and Batu city have high competiveness. Other districts like Sidoarjo, Mojokerto, Jombang, Gresik and several cities like Kediri, Malang, Mojokerto, Mediun, and Surabaya are included in the Quadrant I. These districts and cities are characteristically industrial city which the development is quite fast. It can be shown from the typology of region strength, climate infestation, and public services that show they are in top ranking region in East Java.

Banyuwangi district that is a slight far from industrial area is included in the quadrant I based on the result of typology of public service and region strength, Banyuwangi stand on the top rank of 38 districts or cities of East Java. Furthermore, the essential point that these regions should be aware of is not to be satisfy with all the achievements. Since, they will face stronger rivalry in the future called the regulation of ASEAN free market or Asian Economic Community (AEC). In AEC era, East Java regions are not competing with each other. They start to compete with other countries, mainly in the case of product and labor. Therefore, those Quadrant I regions should keep their competiveness in maintaining their product due to the possibility of regional government cannot maintain the product's rivalry produced by their region, a lot of ASEAN countries' products will enter East Java local market. Thus, the region economic performance will decrease too.

Second is Quadrant II. Quadrant II is quadrant that refers to the condition of high economic performance but low competiveness. A region or city that is included in the category quadrant II generally is a region that has high level of region strength but low in the public service facility and climate infestation. The regions or cities that included in this quadrant II are Bojonegoro, Nganjuk, Lamongan, Pasuruan, Jember, Lumajang, Kediri, Blitar, Tulungagung, and Trenggalek. The rivalry of these districts or cities is in the mid ranking of 38 districts or cities in East Java. 
The main point that should be pointed out in this quadrant is how to anticipate the low rivalry in these regions. There will be possibilities that the investors in these regions will move to others place with high rivalry. The movement of the investors will impact to the decreasing of economic performance. If it happened, these regions in the category Quadrant II would be down to the Quadrant IV (where the economic performance and competiveness is low).

Third is Quadrant III. Quadrant III is quadrant that refers to low economic performance but high rivalry. The districts or cities in this quadrant have a privilege both in the natural resources and human resources, and also adequate facilities. However the economic development in the regions included in this quadrant is low. The productivity is also not really good. Those districts or cities are Ponorogo, Magetan, Ngawi, Blitar, and Pasuruan.

The characteristic of Quadrant III is the high level of competitiveness. However, this characteristic has not optimized the competitiveness of the region to be the power of the region yet. Thus, this region cannot increase the economic growth in its region. The important thing is that this quadrant has to optimize the power of the region competitiveness in order to interact the investors. For instance, they can promote and give facilities in some sectors, especially for the superior sector of the region.

Fourth is Quadrant IV. Quadrant IV represents the low level of economic performance and competitiveness. The district or the city which is considered as Quadrant IV is generally having poor public facilities and low investment level. The regions of Quadrant IV are considered as developing region. It is indicated by low level of economic performance, economic growth and food production. The regions which considered as Quadrant IV are Sumenep District, Pamekasan, Sampang, Bangkalan, Tuban, Madiun, Probolinggo, Bondowoso, Situbondo and Pacitan. Generally, the districts/cities in this quadrant are placed on the lowest ranks of 38 districts/cities of East Java Province in terms of indicator of regional power achievement, investment and public service facilities.

Low economics performance of Quadrant IV regions is related to the geographic condition. Most of the regions have limited accessibility that result from lack of physical infrastructure such as roads, bridges and electricity. These weaknesses are not sufficient to support a big scale investor. For instance, in Madura Island there are some regions which get an access of electricity and paved road. This condition obstructs the economic growth and activity.

\subsection{The Effect of Region Competitiveness towards the Economics Performance}

The panel data analysis of region power value $\left(X_{1}\right)$, public service facilities $\left(\mathrm{X}_{2}\right)$, Investment Climate $\left(\mathrm{X}_{3}\right)$ and Region Competitiveness $\left(\mathrm{X}_{4}\right)$ towards the Economics Performance $(Y)$ of districts/cities in the East Java is using Random Effect approach. The researcher tended to use this model based on the 
consideration of different intercept value of each region. It indicated that every region has different characteristic. The other consideration of the researcher to conduct this study was the residual value which is related to time and individual.

The value of $\beta_{0}$ Constanta of each district/city showed that the highest $\beta_{0}$ value was reached by Tuban $=-5.669$ that meant Economics Performance (LY) was $5,669 \%$ while Region Power $\left(\mathrm{LX}_{1}\right)$ and Public Service Facilities $\left(\mathrm{LX}_{2}\right)$, Investment Climate $\left(L X_{3}\right)$ and Region Competitiveness $\left(L X_{4}\right)$ was equal or zero (constant). Whereas, the lowest $\beta_{0}$ value was indicated on Pamekasan District $=-6.3443$ that meant Economics Performance (LY) was - 6.3443\% while Region Power ( $\left.\mathrm{LX}_{1}\right)$, Public Service Facilities $\left(\mathrm{LX}_{2}\right)$, Investment Climate $\left(\mathrm{LX}_{3}\right)$ and Region Competitiveness $\left(L X_{4}\right)$ was equal or zero (constant). The results were also indicated the dependency level of Economics Performance towards the competitiveness. If it has high value, then the dependency of Economics Performance towards the competitiveness is low and vice versa.

The result of $\beta_{1}$ value of the coefficient regression of Region Power Variable $\left(L X_{1}\right)$ for every district/city of East Java showed 0.1025 . It indicated a positive effect between Region Power towards Economic Performance that was $0.1025 \%$. If Region Power $\left(L X_{1}\right)$ increased on 1\%, thus Economic Performance (LY) will be increased on $0.1025 \%$ and vice versa. If Region Power $\left(L X_{1}\right)$ decreased by $1 \%$, thus Economic Performance (LY) will be decreased by $0.1025 \%$.

On the other hand, the result of $\beta_{2}$ value of the coefficient regression of Public Service Facilities variable $\left(\mathrm{LX}_{2}\right)$ of every district/city of East Java showed 0.6392 . It indicated a positive effect between Public Service Facilities towards Economics Performance on $0.6392 \%$. If Public Service Facilities $\left(\mathrm{LX}_{2}\right)$ increased on $1 \%$, thus Economic Performance (LY) will be increased on $0.6392 \%$ and vice versa. If Public Service Facilities $\left(\mathrm{LX}_{2}\right)$ decreased by $1 \%$, thus Economics Performance will be decreased by $0.6392 \%$.

Based on the result of panel data regression and significant test, it can be concluded that Regional Strength $\left(X_{1}\right)$ Public Service Facilities $\left(X_{2}\right)$, Investment Climate $\left(X_{3}\right)$ and Regional Competitiveness $\left(X_{4}\right)$ have positive impact towards the related variable (Economic Performance).

Based on the determination coefficient score $\mathrm{R}^{2}$ which was 0.4461 meant that $44.61 \%$ of Economic Performance variable would be explained by the independent variable. Those consisted of regional strength, Public Service Facilities, Investment Climate, and Regional Competitiveness. While, the rest $55.39 \%$ of Economic Performance variable would be explained by other variables which is not discussed in this study.

In order to find out variables that predominantly influence on the magnitude of Regency/City Economic Performance in East Java during the period of the study, it can be seen in the probability value. Independent variable that has a low probability 
value indicated that the variable was predominantly influence on the dependent variable.

Based on the calculation result, by comparing the probability values of each variable, it can be concluded that variable that predominantly influence on the magnitude of economic performance was public service facilities. While, the second, the third and the fourth lowest probability values were competitiveness, regional strength, and investment climate. Because of the high role of public facility, then, a leadership role is needed to improve the success of regional economic performance. This is as submitted by Muchiri (1999) and Ssenyonga (2012) that the importance of the leader's role in the public service facility.

Based on the regression analysis, it can be concluded that although it only $44.61 \%$, Competitiveness can influence on the economic performance. This result is in line with the result of competitiveness typology which is only $31.58 \%$ was region that has economic performance and high competitiveness (quadrant I). Meanwhile, even though the competitiveness level was low, there was $26.32 \%$ of region which have high economic performance (quadrant II). It is because the regional economic performance which located in quadrant II was more influenced by variables beyond the competitiveness. As well as in the Quadrant III, region with the total of $13.16 \%$ was the region which has high competitiveness, but not yet improving the economic performance. It means that factors beyond the competitiveness such as leadership factor (regional government) and the use of technology were highly determine the improvement of economic performance.

The result of this study generally concluded that there was $31.58 \%$ of region in the East Java belongs to category I which has economic performance and high competitiveness, and $26.32 \%$ of them is belong to category II which has high economic performance and low competitiveness. In addition, there was $13.16 \%$ of region belongs to category III which meant that the economic performance was low and the competitiveness was high, while the rest $26.31 \%$ belongs to category III which means that the economic performance and the competitiveness was low.

This result of this study is less in line with the findings of the previous study which was conducted by Regional Autonomy Watch (KPPOD) with United States Agency of Improvement and Development (USAID) and The Asia Foundation. They states that the majority which was $47.6 \%$ of the district area in East Java predicated $\mathrm{E}$ and $35.2 \%$ predicated $\mathrm{D}$, while $\mathrm{A}$ and $\mathrm{B}$ predicate respectively were $5.8 \%$ (KPPOD, 2007).

In this study, district/city in the Quadrant I (competitiveness and high economic performance) or equivalent with A predicate in the previous study was $31,58 \%$ which consisted of Malang District, Banyuwangi, Sidoarjo, Mojokerto, Jombang, Gresik, Kediri City, Mojokerto City, Madiun City, Surabaya City and Batu City. Those were different from the result of study from United States Agency of Improvement and Development (USAID) and The Asia Foundation. They stated that only $5 \%$ of region belongs to category $A$. 
Similarly with category $B$, the result of the study from United States Agency of Improvement and Development (USAID) and The Asia Foundation stated that only $5 \%$ of region that belongs to category $B$. While, this study found that there was $26,32 \%$ of region that belongs to quadrant II or equivalent with category $B$ in the USAID study. Whereas, the rest or most of the USAID and The Asia study found that $47,6 \%$ of the district area in East Java predicated $E$ and $35,2 \%$ predicated $\mathrm{D}$. In contrast, this study found that $15,79 \%$ was in the quadrant III (equivalent with predicate C) meant that economic performance region was low and the competitiveness was high. Whereas, region in the quadrant IV (equivalent with predicate E) was region that has high economic performance and low competitiveness which was $26,32 \%$. There are several factors that caused the differences of the result of the study, which are: First, USAID and The Asia Foundation were conducted a study of competitiveness that is seen only from the aspect of regional investment. Meanwhile, in this study, the competitiveness is seen based on the three aspects which are regional strength, service, and investment climate.

This study contributes more varied competitiveness measurement variables which not only measure from the investment aspect, but also regional strength aspect and regional service. The determination of the regional performance measurement aspect refers to local government performance appraisal aspect which is stated on the Ministry of Home Affairs Regulations (Permendagri) No 54 of 2010. Therefore, the determination of the regional performance measurement in this study could be the raw variable to measure the competitiveness of district/city in Indonesia. Second, United States Agency of Improvement and Development (USAID) and The Asia Foundation conducted a study of regional competitiveness by taking samples in 169 districts and 59 cities across Indonesia. That study leads to a very high standard of appraisal gap, while the study was conducted on 38 districts/ cities in East Java that the differences in the assessment standard was not in the high gap.

This research will give constribution of the measurement method of region competitiveness that are relatively more balanced or real by means of measuring the competitiveness on the narrow space is in province space. Therefore, the measurement will avoid comparable level in relatively balance, compared to the larger level space as in the national.

Third, United States Agency of Improvement and Development (USAID) also The Asia Foundation have not been discuss about the relation between the region competitiveness variable and region performance. The study has stop on comparing process of competitiveness in each region. Therefore, this result study has low recommendation for policy-making in the effort to improving the region of economic performance.

However, this study was succesful indicate the effect of region competitiveness variable to economic performance. The result study suggests that 
competitiveness which consists of indicators of the strength region, the facilities of public services, and investment climate influence economic performance. It can be shown that regions where place in Quadrant I is region which has highly economic performance and competitiveness. Statistically, based on the result of t-test and ftest shown that three indicators, either partially or simultaneously were influence economic performance in a region.

The competitiveness variable influenced economic performance about $41.1 \%$. It was similarly with the result of competitiveness typology which only $31.58 \%$ that region had high economic performance and competitiveness (Quadrant I). Meanwhile 26.32 \% was region that had high economic performance however level of competitiveness was low (Quadrant II). It meant that region economic performance in Quadrant II were more affected by variable beyond competitiveness. Similarly, the region in Quadrant III about $15.79 \%$ was region that had high competitiveness nevertheless it cannot increase economic performance yet. It can be concluded that the factors beyond competitiveness, for instance leadership factor (region government), the use of technology was very decisive in improving economic performance.

Based on the result study indicated that this study were support competitiveness teory on national level, according to Porter (1990) and Porter (1996), they said that the competitive of region (for example province or city/district) highly dependent on capacity of society (especially the entrepreneur) to innovate and continously update, and technology and Human Resources (Prasetyo, 2008). Therefore, it contrasted with the advantages of comparatif, the advantages of competitive was very dynamic which caused by technology change steadily, the quality of Human Resources develop continously, so the advantages of competitive has more big role on region productivity (Soebagyo, Triyono, \& Cahyono, 2013).

This study was in accordance with the result study of Garelli (2003), he presented his result study on The World Competitive Yearbook with eighth competitiveness factors were affect economic performance, for instance : Domestic Economy, Internationalization, Government, Management, Finance, Infrastructure, Science and technology, Human. Similarly, the result study World Economic Forum (2016), which presented the result study in The Global Competitiveness Report, by eighth factors such as Civil Society, Openness, Government, Management, Finance, Infrastructure, Technology, and labor.

It strengthened with varied result of the previous study such as Irawati et al., (2008), Cahyono \& Kaluge (2011), and Yanuar (2006) who are conclude their study that the facilities/ public services has a big role to economic performance. Irawati et al., (2008) stated that districts and cities located on land have a higher level of competitiveness due to the availability of infrastructure, the spread of economic growth with adjacent areas, and the attractiveness of the population to live in land areas that are able to encourage high welfare. 
Cahyono \& Kaluge (2011) in his research also stated that the availability of public infrastructure (roads, electricity and telephone) in the long run would be able to influence the Perkapita Gross Domestic Product in Indonesia. In line with the results of these studies, Yanuar (2006) also states that the physical capital, road, telephone line, health, and education infrastructure are positively affected by the economic output.

The result of this study also emphasize related with the measurement of competitiveness according to Porter (1990), which argue that human resources and asset (investment) which more important in improving economic performance when compared just rely on natural resources. It can be seen in regions where placed on Quadrant I was regions that has high quality of human resources and asset however natural resources are limited.

\section{CONCLUSION}

The results of this study indicated that the indicators have a big role on economic performance were the aspect of public services. Thus, the priority of policy in general was the improvement of public services in terms of order regulation/regulation, provision of infrastructure, and readiness of human resources. Improving the quality of human resources should also be a priority because based on the results of research indicates that variable human resources were an important factor in the formation of competitiveness.

In the contexts of improving economic performance affected by the position of competitiveness in each region, affects the differences of economic potential and geographical region. Besides, it is caused by the strength of region, the facilities of public services, and investment climate. Based on the analysis result, the development of region-based infrastructure was increasingly important to note. The development of region had a big role to expose rural region isolation in order to increase region development and equalize the development of economic region.

In order to the equity of East Java region that all regions able to get position in quadrant I, so that it is crucial to increase services of economy activity in all region marked by the development of transportation infrastructure that reach the rural region in order to increase the accessibility at all regions. Moreover, development in urban areas was directed to its development in order to be more organized with the support of regional development management tools that can accommodate region development for the growth of each region and the harmony of urban, small, medium, and rural areas that exist. 


\section{REFERENCES}

Abdullah, P., Alisjahbana, A. S., \& Efendi, B. N. 2002. Daya Saing Daerah, Konsep dan Pengukurannya di Indonesia. Yogyakarta: BPFE UGM.

Abdullah, P., Alisjahbana, A. S., \& Efendi, B. N. 2002. Daya Saing Daerah, Konsep dan Pengukurannya di Indonesia. Yogyakarta: BPFE UGM.

Badan Pusat Statistik. 2017. Gini Ratio Provinsi 2002-2017.

Badan Pusat Statistik Jawa Timur. 2017. Gini Rasio Menurut Kabupaten/Kota Tahun 2008 - 2015.

Brundtland, G. H. 1985. World Commission on Environment and Development. Environmental Policy and Law, 14(1), pp. 26-30.

Budihardjo, E., \& Sudjarto, D. 1999. Kota Berkelanjutan. Bandung: Alumni.

Cahyono, E. F., \& Kaluge, D. 2011. Analisis Pengaruh Infrastruktur Publik Terhadap Produk Domestik Bruto Perkapita di Indonesia. Iqtishoduna, 7(2).

Garelli, S. 2003. Competitiveness of Nations: The Fundamentals. IMD World Competitiveness Yearbook.

Irawati, I., Urufi, Z., Isaias, E., \& Resobeoen, R. 2008. Pengukuran Tingkat Daya Saing Daerah Berdasarkan Variabel Perekonomian Daerah, Variabel Infrastruktur Dan Sumber Daya Alam, Serta Variabel Sumber Daya Manusia Di Wilayah Provinsi Sulawesi Tenggara. In Prosiding INSAHP5 (pp. 978-979).

KPPOD. 2007. Tata Kelola Ekonomi Daerah di Indonesia 2007. Jakarta.

Muchiri, M. 1999. The Role of Transmormational Leadership in Reenginering the Public Administration of the Future. JKAP (Jurnal Kebijakan Dan Administrasi Publik), 3(2), pp. 41-66.

Porter, M. E. 1990. The Competitive Advantage of Nations. Harvard Business Review, 68(2), pp. 73-93.

Porter, M. E. 1996. Competitive Advantage, Agglomeration Economies, and Regional Policy. International Regional Science Review, 19(1-2), 85-90.

Prasetyo, P. E. 2008. The Quality of Growth: Peran Teknologi dan Investasi Human Capital sebagai Pemacu Pertumbuhan Ekonomi Berkualitas. JEJAK: Jurnal EKonomi Dan Kebijakan, 1(1).

Santoso, E. B. 2009. Daya Saing Kota-Kota Besar di Indonesia. In Seminar Nasional Perencanaan Wilayah dan Kota "Menuju Penataan Ruang Perkotaan yang Berkelanjutan, Berdaya Saing, dan Berotonomi." 
Soebagyo, D., Triyono, \& Cahyono, Y. T. 2013. Daya Saing Daerah dan Implikasinya terhadap Pembangunan. Jurnal Ekonomi Pembangunan: Kajian Masalah Ekonomi Dan Pembangunan, 14(2), pp. 160-171.

Ssenyonga, M. 2012. Innovative Management Styles, Organizational Structures, and Strategies in Turbulent Times. JKAP (Jurnal Kebijakan Dan Administrasi Publik), 16(1), 89-120.

Suliswanto, M. S. W. 2016. TINGKAT KETERBUKAAN EKONOMI. Neo-Bis, 10(1), pp. 33-48.

Suliswanto, M.S.W., and Kaluge, D. 2010. Globalization and gross domestic product construction in Asean. Economic Journal of Emerging Markets, 2(2), pp. 157-170.

Syafrizal. 1997. Pertumbuhan Ekonomi dan Ketimpangan Regional Wilayah Indonesia Bagian Barat. Majalah Prisma Edisi Maret, pp. 27-38.

World Bank Institute. 2001. City Strategy to Reduce Urban Proverty Trough Local Economic Development: City Strategy and Governance, International Bank of Reconstruction and Development.

World Economic Forum. 2016. The Global Competitiveness Report.

Yanuar, R. 2006. Kaitan Pembangunan Infrastruktur dan Pertumbuhan Output serta Dampaknya terhadap Kesenjangan di Indonesia. Institut Pertanian Bogor. 